\title{
ERRATUM
}

Ayhan Sogut - Ceyda Acun - Kubilay Aydin •

Nazan Tomac $\cdot$ Fatma Demeril $\cdot$ Cigdem Aktuglu

\section{Isovaleric acidaemia: cranial CT and MRI findings}

Published online: 5 July 2006

C) Springer-Verlag 2006

\section{Pediatr Radiol (2004) 34:160-162}

The name of the fourth author is Nazan Tomac.

The online version of the original article can be found at http://dx. doi.org.10.1007/s00247-003-1049-8.

\author{
A. Sogut · C. Acun · N. Tomac · F. Demeril \\ Department of Paediatrics, Karaelmas University, \\ Zonguldak, Turkey \\ K. Aydin $(\bowtie)$ \\ Department of Radiology, Istanbul Medical School, \\ Istanbul University, \\ Camlikyolu, B. mehmetpasa sokak yavuz apt. No:10/10, \\ Etiler, \\ Istanbul, Turkey \\ e-mail: dr.aydink@superonline.com \\ Tel.: +90-533-2214257 \\ Fax: +90-533-2211380 \\ C. Aktuglu \\ Department of Paediatrics, Cerrahpasa Medical School, \\ Istanbul University, \\ Istanbul, Turkey
}

